\title{
Frequency of Spontaneous Bacterial Peritonitis in Patients of Liver Cirrhosis with Ascites at Tanta University Hospitals
}

\author{
SHEREEN A. ABOGALALA, M.Sc.*; MUHAMMAD T. ABD EL-GHAFAR, M.D.**; \\ ABDALLAH A. EL-SAWY, M.D.* and MABROUK R. AL-SHEIKH, M.D.* \\ The Departments of Internal Medicine* and Clinical Pathology**, Faculty of Medicine, Tanta University
}

\begin{abstract}
Background: Liver cirrhosis represents one of the major causes of death worldwide. Many complications can be detected in liver cirrhosis. Among these complications is ascites which seems to be the most frequent one. Patients with cirrhosis and ascites show a higher susceptibility to bacterial infections mainly because of the inadequate defense mechanisms. In those patients, the most frequent infectious complication that occurs and at the same time the most severe one is spontaneous bacterial peritonitis.
\end{abstract}

Aim of Study: To identify the frequency of spontaneous bacterial peritonitis in patients of liver cirrhosis with ascites at Tanta University Hospitals.

Patients and Methods: This study included three hundred patients with liver cirrhosis and ascites. Data were collected including; clinical, demographic and laboratory data. Ascitic fluid analysis and/or culture were done for diagnosis of SBP. Statistical analysis was carried out for all collected data using IBM \& SPSS Version 20. Statistical significance was determined at a $p$-value $<0.05$.

Results: The frequency of spontaneous bacterial peritonitis in patients of liver cirrhosis with ascites at Tanta University Hospitals represented by $41.7 \%$.

Conclusions: The frequency of spontaneous bacterial peritonitis in patients of liver cirrhosis with ascites at Tanta University Hospitals represented by $41.7 \%$ of the collected cases.

Key Words: Liver cirrhosis - Ascites - Spontaneous bacterial peritonitis.

\section{Introduction}

LIVER cirrhosis is the final common pathological pathway of liver damage arising from a wide variety of chronic liver diseases [1]. Although the causes of liver cirrhosis are multifactorial, there are some pathological characteristics that are common to all cases of liver cirrhosis including degeneration and necrosis of hepatocytes, and replacement of liver

Correspondence to: Dr. Shereen A. Abogalala, The Department of Internal Medicine, Faculty of Medicine, Tanta University parenchyma by fibrotic tissues and regenerative nodules, and loss of liver function [2]. Most complications of liver cirrhosis are either due to portal hypertension and/or to progressive hepatic dysfunction. Hepatocellular carcinoma also may be viewed as a complication of liver cirrhosis especially when it develops in the course of chronic viral infection, hereditary hemochromatosis, $\alpha_{1}$ antitrypsin deficiency, chronic alcoholic and nonalcoholic fatty liver disease [3]. The presence of ascites is the commonest complication in patients with cirrhosis. Approximately $60 \%$ of cirrhotics end up exhibiting it during the course of their disease. The development of ascites indicates a clear decompensation of the disease and is generally associated with a bad prognosis, with an approximately $40 \%$ of 1 -year mortality [4]. The development of ascites is associated with a poor prognosis and impaired quality of life in patients with cirrhosis [5]. The diagnosis of SBP is based on diagnostic paracentesis [6]. The greatest sensitivity for the diagnosis of SBP is reached with a cutoff neutrophil count of 250 cells $/ \mathrm{mm}^{3}$ in ascitic fluid sample, although the greatest specificity is reached with acutoff of 500 cells $/ \mathrm{mm}^{3}$ in it. Emperical antibiotic therapy must be initiated immediately after thediagnosis of SBP without the results of ascitic fluid culture [7].

\section{Patients and Methods}

Three hundred patients with liver cirrhosis and ascites who were admitted at Department of Internal Medicine at Tanta University Hospitals or attending at its outpatient clinic in the period from March 2017 to March 2018 and who were fulfilled the inclusion criteria of our study were included in this study. All participant provided informed written consent and the study was approved by Tanta Faculty of Medicine Ethical Committee. 
All patients were subjected to ascitic fluid analysis and/or ascitic fluid culture for diagnosis of spontaneous bacterial peritonitis.

\section{Inclusion criteria:}

Patients with chronic liver disease and ascites due to liver cirrhosis.

\section{Exclusion criteria:}

Those who were suspected to have secondary peritonitis such as perforated colon, ruptured appendix... etc. taking.

All patients were subjected to: Thorough history

Complete clinical examination. Laboratory investigations include complete blood picture. Liver enzymes (ALT \& AST), serum albumin. serum creatinine, prothrombin time, activity \& INR.

Radiological investigations including: Abdominal ultrasound.

\section{Sampling and laboratory investigations:}

Sampling and all laboratory investigations were done in Clinical Pathology Department, Tanta University Hospitals.

Ascitic fluid analysis and culture: Diagnosis of spontaneous bacterial peritonitis will be based on increased ascitic fluid absolute Polymorphnuclear Leukocyte $(\mathrm{PMN})$ count $\left(<250\right.$ cells $\left./ \mathrm{mm}^{3}\right)$ and/or positive ascitic fluid bacterial culture [8]

Once the diagnosis of liver cirrhosis with ascites was confirmed, abdominal paracentesis was carried out. Diagnostic paracentesis was performed for all patients on admission under strict aseptic conditions. About $30 \mathrm{ml}$ of ascitic fluid was collected from each patient. Ascitic fluid sample were examined physically and chemically.

\section{Physical examination:}

Include the following:

Aspect: Opaque specimens were detected through newsprint readability loss.

Colour: Ascitic fluid is generally straw colored or yellow tinged. Cloudiness or opaque appearance is due to the presence of neutrophils.

\section{Chemical analysis:}

Include the following:

$P H$ : It was detected by reagent strip indicators methyl red and bromothymol blue which give a range of orange, green, and blue colors as the $\mathrm{pH}$ rises.

Specific gravity: Was detected by reagent strip polyelectrolyte, indicator substance, and buffer. The principle of this method is based on the $\mathrm{pKa}$ change of pretreated polyelectrolytes in relation to the ionic concentration of the fluid.

Protein: Measured by biuret method.

Glucose: Measured by glucose oxidase method.

Serum albumin ascitic fluid gradient: Measured by dye binding (BCG) method. Spontaneous Bacterial Peritonitis (SBP) is commonly associated with low total protein $(<3.0 \mathrm{~g} / \mathrm{dL})$ and a high serumascites albumin gradient $(>1.1 \mathrm{~g} / \mathrm{dL})$.

\section{Microscopic examination:}

Cell counts: Total leucocytic count performed using manual hemocytometer methods; and or automated cell counts.

Differential leukocyte count and cytology: Examination was performed on a stained smear, prepared by cytocentrifugation and with the air-dried smear stained with a Romanowski stain.

Statistical presentation and analysis of the present study was conducted, using the mean, standard deviation and it normally distributed according to K-S test while categorical data were presented as number and percentage.

To compare between positive spontaneous bacterial peritonitis patients and negative spontaneous bacterial peritonitis patients in complete blood count and prothrombin studies, liver functions \& kidney functions and some characteristics of ascitic fluid analysis as (albumin, protein, glucose,...) independent $t$-test was used to detect a difference in clinical data and some characteristics of ascitic fluid as (aspect and colour) pearson chisquare test and Monte Carlo exact $p$-value was used $p$-values $<0.05$ were considered statistically significant.

Data were analyzed using IBM $\odot$ SPSS $\odot$ Statistics Version 20 (IBM@ Corp., Armonk, NY, USA).

\section{Results}

In this study it was found that frequency of spontaneous bacterial peritonitis in patients of liver cirrhosis with ascites at Tanta University Hospitals which constitute $41.7 \%$ of cases (Table 1).

There was statistically significant difference as regards $\mathrm{Hb}$, WBCs count and prothrombin ac- 
tivity ( $p$-value $<0.05$ ), while there are no significant differences as regards platelets, INR and prothrombin time (Table 2).

There was statistically significant differences as regards AST and ALT levels $(p<0.001 *)$. Also it illustrate that there is statistically significant difference as regards urea level $(t=2.899, p=$ $\left.0.004^{*}\right)$, at the same time the results revealed that there is statistically significant difference as regard serum creatinine level $(t=2.56, p=0.01 *)$, while there are no significant difference between them as regard serum albumin and serum bilirubin level as $p$-value $>0.05$ (Table 3 ).

There was significance difference between patients in percentage of cases with asymptomatic presentation as in positive SBP $13.6 \%$ compared to $96 \%$ in negative SBP, $(\chi=209.4, p<.001 *)$ Fig. (1).

There was significance difference between them in percentage of cases with abdominal pain as in positive SBP $84.8 \%$ and $0.6 \%$ in negative SBP $\left(\chi^{2}=225.45, p<.001 *\right)$ Fig. (2).

In this study it was found that $80 \%$ of cases in positive SBP were feverish while only. $6 \%$ in negative SBP presenting ${ }_{2}$ with fever and this difference was significant, $\left(\chi^{2}=205, p<.001 *\right)$.

Table (1): Frequency of spontaneous bacterial peritonitis in patients of liver cirrhosis with ascites at Tanta University Hospitals.

\begin{tabular}{lccccc}
\hline & \multicolumn{2}{c}{ Positive } & & \multicolumn{2}{c}{ Negative } \\
\cline { 2 - 3 } \cline { 6 - 7 } & No. & $\%$ & & No. & $\%$ \\
\hline Spontaneous Bacterial Peritonitis & 125 & 41.7 & & 175 & 58.3 \\
\hline
\end{tabular}

Table (2): Comparison between positive spontaneous bacterial peritonitis patients and negative spontaneous bacterial peritonitis patients as regard complete blood count and prothrombin studies.

\begin{tabular}{|c|c|c|c|}
\hline & $\begin{array}{c}\text { Positive } \\
\text { spontaneous } \\
\text { bacterial } \\
\text { peritonitis } \\
(\mathrm{N}=125)\end{array}$ & $\begin{array}{l}\text { Negative } \\
\text { spontaneous } \\
\text { bacterial } \\
\text { peritonitis } \\
(\mathrm{N}=175)\end{array}$ & $\begin{array}{c}\text { Test of } \\
\text { significance } \\
(p)\end{array}$ \\
\hline $\begin{array}{l}H b(g / d l): \\
\quad \text { Mean } \pm \mathrm{SD}\end{array}$ & $10.72 \pm 1.82$ & $9.96 \pm 1.22$ & $\begin{array}{l}(t=4.06 \\
p<.001 *)\end{array}$ \\
\hline $\begin{array}{l}\text { WBCs }(* 1000 / u l): \\
\quad \text { Mean } \pm \text { SD }\end{array}$ & $11.96 \pm 11.99$ & $7.16 \pm 3.53$ & $\begin{array}{l}(t=4.34 \\
p<.001 *)\end{array}$ \\
\hline $\begin{array}{l}\text { Platelets }(* 1000 / u l): \\
\text { Mean } \pm \mathrm{SD}\end{array}$ & $120.2 \pm 89.93$ & $129.13 \pm 57.76$ & $\begin{array}{l}(t=-1.04, \\
p=.296)\end{array}$ \\
\hline $\begin{array}{l}\text { INR: } \\
\quad \text { Mean } \pm \mathrm{SD}\end{array}$ & $1.56 \pm .29$ & $1.55 \pm .532$ & $\begin{array}{l}(t=.181, \\
p=.85)\end{array}$ \\
\hline $\begin{array}{l}P T(\text { seconds): } \\
\quad \text { Mean } \pm \text { SD }\end{array}$ & $17 \pm 2.39$ & $16.43 \pm 2.73$ & $\begin{array}{l}(t=1.87 \\
p=.06)\end{array}$ \\
\hline $\begin{array}{l}P A(\%): \\
\quad \text { Mean } \pm \mathrm{SD}\end{array}$ & $61.33 \pm 12.09$ & $65.97 \pm 16.17$ & $\begin{array}{l}(t=-2.87 \\
\left.p=.005^{*}\right)\end{array}$ \\
\hline
\end{tabular}

Table (3): Comparison between positive spontaneous bacterial peritonitis patients and negative spontaneous bacterial peritonitis patients as regard liver functions $\&$ kidney functions.

\begin{tabular}{|c|c|c|c|}
\hline & $\begin{array}{l}\text { Positive } \\
\text { spontaneous } \\
\text { bacterial } \\
\text { peritonitis } \\
(\mathrm{N}=125)\end{array}$ & $\begin{array}{l}\text { Negative } \\
\text { spontaneous } \\
\text { bacterial } \\
\text { peritonitis } \\
(\mathrm{N}=175)\end{array}$ & $\begin{array}{c}\text { Test of } \\
\text { significance } \\
(p)\end{array}$ \\
\hline $\begin{array}{c}\text { Albumin }(g / d l): \\
\text { Mean } \pm \text { SD }\end{array}$ & $2.67 \pm .380$ & $2.74 \pm .715$ & $\begin{array}{l}(t=-1.098, \\
p=.273)\end{array}$ \\
\hline $\begin{array}{l}\text { Bilirubin }(m g / d l): \\
\quad \text { Mean } \pm \text { SD }\end{array}$ & $1.95 \pm 1.5$ & $1.79 \pm .463$ & $\begin{array}{l}(t=1.419, \\
p=.157)\end{array}$ \\
\hline $\begin{array}{l}A S T(U / L): \\
\quad \text { Mean } \pm \mathrm{SD}\end{array}$ & $57.96 \pm 37.41$ & $39.7 \pm 25.64$ & $\begin{array}{l}(t=4.721, \\
p<.001 *)\end{array}$ \\
\hline $\begin{array}{l}A L T(U / L): \\
\quad \text { Mean } \pm \mathrm{SD}\end{array}$ & $59.89 \pm 46.23$ & $39.99 \pm 35.707$ & $\begin{array}{l}(t=4.029 \\
p<.001 *)\end{array}$ \\
\hline $\begin{array}{l}\text { Urea }(m g / d l): \\
\text { Mean } \pm \text { SD }\end{array}$ & $95.81 \pm 48.14$ & $77.39 \pm 61.8$ & $\begin{array}{l}(t=2.899 \\
\left.p=.004^{*}\right)\end{array}$ \\
\hline $\begin{array}{l}\text { Creatinine }(m g / d l): \\
\quad \text { Mean } \pm \text { SD }\end{array}$ & $1.98 \pm 1.08$ & $1.65 \pm 1.13$ & $\begin{array}{l}(t=2.56 \\
p=.01 *)\end{array}$ \\
\hline
\end{tabular}

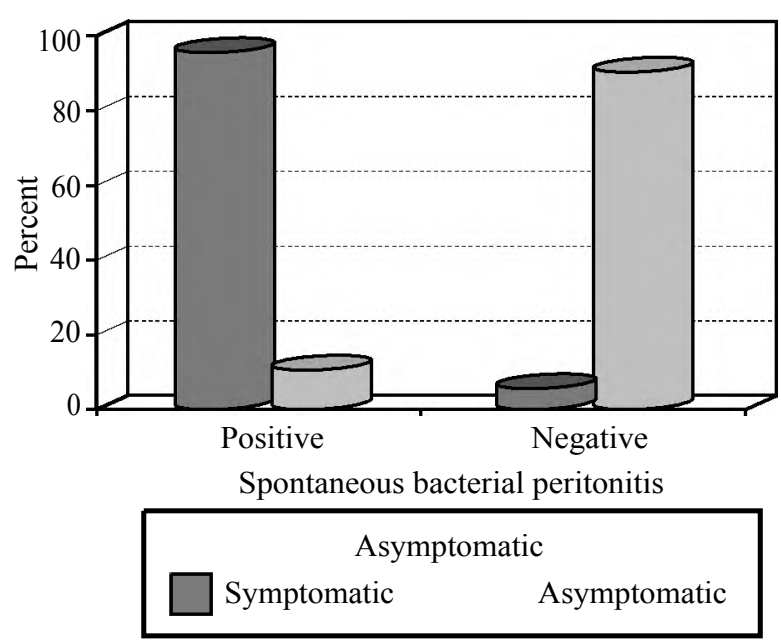

Fig. (1): Comparison between positive SBP patients and negative SBP patients as regard symptoms.

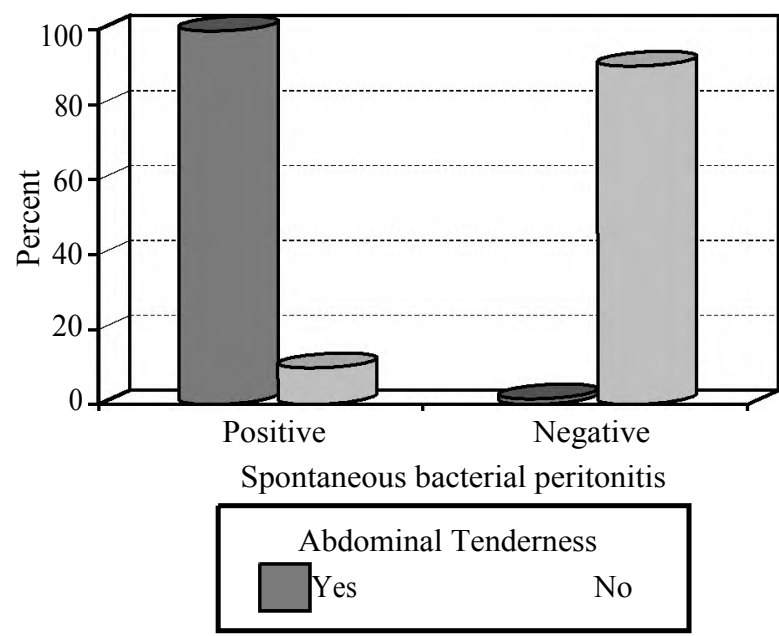

Fig. (2): Comparison between positive SBP patients and negative SBP patients as regard abdominal pain. 


\section{Discussion}

Cirrhosis is defined as the histological development of regenerative nodules surrounded by fibrous bands in response to chronic liver injury, which leads to portal hypertension and end-stage liver disease. Recent advances in the understanding of the natural history and pathophysiology of cirrhosis, and in treatment of its complications, have resulted in improved management, quality of life, and life expectancy of patients. Liver transplantation remains the only curative option for a selected group of patients, but pharmacological treatments that can halt progression to decompensated cirrhosis or even reverse cirrhosis are currently being developed.

Spontaneous Bacterial Peritonitis (SBP) is a serious and potentially life-threatening complication in patients with decompensated liver cirrhosis. It appears to be a consequence of impaired defense mechanisms and an increased susceptibility to bacterial infections in cirrhotic patients with ascites in the absence of any intra-abdominal source of infection (e.g. intestinal perforations or abscesses) [9].

For the diagnosis of spontaneous bacterial peritonitis, the polymorphonuclear leucocytes (PMN) from the ascitic fluid obtained by paracentesis must exceed $\geq 250 \mathrm{cell} / \mathrm{mm}$ and from bacterial culture only one pathogenic microorganism must be isolated [10].

In this study we tried to identify the frequency and the clinical presentations of spontaneous bacterial peritonitis in patients of liver cirrhosis with ascites at Tanta University Hospitals.

First of all our results evaluated the demographic criteria of our patients and we found that, the majority $(37.5 \%)$ of our patients was between 51 60 years, while the minority $11.6 \%$ was from 31 40 years age group, at the same time we found male predominance in our patients with male to female ratio was 1.3:1, all these demographic data comes in agreement with Oladimeji et al., [12] in which male represented $54.8 \%$ and female represented $45.2 \%$ with mean age (62 \pm 9$)$.

In our study the frequency of spontaneous bacterial peritonitis in patients of liver cirrhosis with ascites at Tanta University Hospitals was found to be $41.7 \%$ from cases. Oladimeji et al., [12] found that the frequency of spontaneous bacterial peritonitis was $67.7 \%$. This high difference may be contributed to the discrepancy in the number of patients included in each study as our study includes 300 patients while this study includes 31 patients only. According to Kasztelan-Szczerbinska B et al., [10] spontaneous bacterial peritonitis was diagnosed in $30 \%$ of all cirrhotic patients with ascites undergoing paracentesis.

Our study has shown that hemoglobin levels were significantly decreased in patients with negative SBP with mean hemoglobin level $(9.96 \pm 1.22$ $\mathrm{gm} / \mathrm{dl}$ ) when compared to patients with positive SBP with mean hemoglobin level $(10.72 \pm 1.82$ $\mathrm{gm} / \mathrm{dl})\left(p\right.$-value ${ }^{<0.001 \%}$. That is in contrast with Caly et al., [13] who found that anemia was more frequently found among infected patients with cirrhosis. On the other hand there was no significant difference in $\mathrm{Hb}$ levels between positive SBP and negative SBP patients according to Papatheodoridis, et al., [14] . At the same time we found that there was significantly increase in WBCs count in positive SBP patients when compared to patients with negative SBP $(p$-value $<0.001 *)$.

This is in agreement with Kasztelan-Szczerbinska B et al., [10] who study the prevalence of spontaneous bacterial peritonitis in asymptomatic patients with decompensated liver cirrhosis.

In the current study, we did not find any significant difference between patients with positive SBP and patients with negative SPB regarding serum albumin and serum bilirubin levels. This is in agreement with Evans et al., [15].

In our study there is significant increase in serum creatinine level in positive SBP when compared to those with negative SBP ( $p$-value $=.01)$, these results are against to Oladimeji et al., [12] who found no significant difference in serum creatinine levels in patients with positive SBP and those with negative SBP, however these results are similar to Follo et al., [16] who study renal impairment after spontaneous bacterial peritonitis in cirrhosis and found significant increase in serum creatinine level in positive SBP than those with cirrhotic ascites $(p$-value $=.001)$ indicating that there was increase in serum creatinine after SBP in cirrhotic patients with ascites.

As regards the clinical presentations of SBP patients, we found that $13.6 \%$ of SBP patients were asymptomatic. Khan et al., [17] found that $5 \%$ of patients of liver cirrhosis with ascites having no symptoms, had spontaneous bacterial peritonitis. However this percentage of asymptomatic SBP is relatively small in relation to symptomatic SBP patients but it is critically important as it signify that absence of SBP symptoms cannot rule out the presence of SBP in liver cirrhosis with ascites. 
In our study, we found that $84.6 \%$ of SBP patient were presented with abdominal pain and those presented with fever in SBP patients represented by $80 \%$ with a high significant difference $(p<.001)$ compared with negative SBP. Khan et al., [18] who study spontaneous bacterial peritonitis in cirrhotic patients with hepatic encephalopathy found that $76 \%$ of patients of SBP with abdominal pain while fever with SBP patients found to be $72 \%$ of all cases. Nearly the same percentage was observed in Iqbal et al., [19]. This indicates the near percentages of these studies to our study and so we can say that abdominal pain and fever are the most common presenting clinical data in SBP patients.

In this study we found that the percent of positive SBP patients with culture negative (CNNA) represents $62.4 \%$ while those with culture positive in the same group represents $37.6 \%$ mainly with E coli. Oladimeji et al., [12] found that culture positive SBP was present in $66.7 \%$ while (CNNA) was found in $33.3 \%$. This difference may be related to low number of patients in this study (12 patients) compared to our study which include 125 positive SBP patients.

Runyon et al., [20] study found that Culturenegative neutrocytic ascites (probable spontaneous bacterial peritonitis) is noted when the ascitic fluid culture results are negative, but the PMN count is 250 cells $/ \mu \mathrm{L}$ or higher. This may happen in as many as $50 \%$ of patients with SBP. This presents nearly similar to the present of our study. These results signify also an important diagnostic critical point of view as negative culture for ascetic fluid cannot rule out presence of SBP.

Regarding ascetic fluid analysis in our study we found no significant difference in ascetic protein level and ascetic albumin level in both positive SBP and negative SBP patients. This is in agreement with Schwabl et al., [21]. Our study shows also that, there is a significant difference in ascitic glucose level in positive SBP patient, this is in agreement with Bar-Meir et al., [22] and in contrast to Runyon et al., [20] who found no significant difference in ascitic glucose level in both positive and negative SBP.

Our results are similar to Runyon et al., [20] who found that there is significant difference in lactate dehydrogenase levels in positive SBP ( $p$ value $<0.001)$.

Schwabl et al., [21] found that there is significant increase in ascitic PMN cell count in positive SBP patients compared with negative SBP ( $p$-value
$=0.007)$. This is in agreement with our study in which also there is increase in total PMN cells in positive patients than negative patients ( $p$-value $<0.001)$.

\section{Conclusions:}

Frequency of spontaneous bacterial peritonitis in patients of liver cirrhosis with ascites at Tanta University Hospitals was represented by $41.7 \%$ of all cases which were collected.

\section{Recommendations:}

In our study, it was found that spontaneous bacterial peritonitis represents high percent of all ascitic patients with cirrhosis $(41.7 \%)$ and from this percent we found that $13.6 \%$ from this cases were asymptomatic. So all cirrhotic patients with ascites even asymptomatic must undergo abdominal paracentesis for ascitic fluid analysis and/or culture as diagnostic for SBP.

\section{References}

1- ASRANI S.K., LARSON J.J., YAWN B., et al.: Underestimation of liver-related mortality in the United States. Gastroenterology, 145 (2): p. 375-82. e2, 2013.

2- ELSHARKAWY A., OAKLEY F. and MANN D.: The role and regulation of hepatic stellate cell apoptosis in reversal of liver fibrosis. Apoptosis, 10 (5): p. 927-39, 2005.

3- DANCYGIER H.: Complications of Liver Cirrhosis, in Clinical Hepatology. Springer, p. 967-1031, 2010.

4- GARCIA-TSAO G.: Current management of the complications of cirrhosis and portal hypertension: Variceal hemorrhage, ascites, and spontaneous bacterial peritonitis. Digestive Diseases, 34 (4): p. 382-6, 2016.

5- TANDON P. and GARCIA-TSAO G.: Bacterial infections, sepsis, and multiorgan failure in cirrhosis. In Seminars in liver disease. () Thieme Medical Publishers, 2008.

6- RIMOLA A., GARCÍA-TSAO G., NAVASA M., et al.: Diagnosis, treatment and prophylaxis of spontaneous bacterial peritonitis: A consensus document. Journal of hepatology, 32 (1): p. 142-53, 2000.

7- WONG F., BERNARDI M., BALK R., et al.: Sepsis in cirrhosis: Report on the 7 th meeting of the International Ascites Club. Gut, 54 (5): p. 718-25, 2005.

8- KHAN D.M., SH A.R., ASHFAQ M., et al.: Frequency of asymptomatic spontaneous bacterial peritonitis in chronic liver disease patients with first presentation of ascites. Annals of King Edward Medical University, 10 (2), 2016

9- SCHUPPAN D. and AFDHAL N.H.: Liver cirrhosis. The Lancet, 371 (9615): p. 838-51, 2008.

10- KASZTELAN-SZCZERBINSKA B., SLOMKA M., CELINSKI K., et al.: Prevalence of spontaneous bacterial peritonitis in asymptomatic inpatients with decompensated liver cirrhosis-a pilot study. Advances in medical sciences, 56 (1): p. 13-7, 2011. 
11- GUARNER C. and SORIANO G.: Bacterial translocation and its consequences in patients with cirrhosis. European journal of gastroenterology \& hepatology, 17 (1): p. $27-$ $31,2005$.

12- OLADIMEJI A.A., TEMI A.P., ADEKUNLE A.E., et al.: Prevalence of spontaneous bacterial peritonitis in liver cirrhosis with ascites. Pan African Medical Journal, 15 (1), 2013.

13- CALY W.R. and STRAUSS E.: A prospective study of bacterial infections in patients with cirrhosis. Journal of hepatology, 18 (3): p. 353-8, 1993.

14-PAPATHEODORIDIS G.V., PATCH D., WEBSTER G.J., et al.: Infection and hemostasis in decompensated cirrhosis: A prospective study using thrombelastography. Hepatology, 29 (4): p. 1085-90, 1999.

15- EVANS L.T., KIM W., POTERUCHA J.J., et al.: Spontaneous bacterial peritonitis in asymptomatic outpatients with cirrhotic ascites. Hepatology, 37 (4): p. 897-901, 2003.

16- FOLLO A., LLOVET J.M., NAVASA M., et al.: Renal impairment after spontaneous bacterial peritonitis in cirrhosis: Incidence, clinical course, predictive factors and prognosis. Hepatology, 20 (6): p. 1495-501, 1994.
17- KHAN F.F., ALI W., KHATTAK A.L., et al.: Frequency of asymptomatic spontaneous bacterial peritonitis in patients of liver cirrhosis with ascites. Pakistan Armed Forces Medical Journal, 64 (2): p. 229-33, 2014.

18- KHAN A.M., ZIAUDDIN A., TAJ H., et al.: Spontaneous bacterial peritonitis in cirrhotic patients with hepatic encephalopathy. KJMS, 8 (2): p. 145, 2015.

19- IQBAL S. and ALAM N.: Incidence of spontaneous Bacterial Peritonitits in Liver Cirrhosis, the Causative Organism and Antibiotic sensitivity. Journal of Postgraduate Medical Institute (Peshawar-Pakistan), 18 (4), 2011.

20- RUNYON B.A.: Monomicrobial nonneutrocytic bacterascites: A variant of spontaneous bacterial peritonitis. Hepatology, 12 (4): p. 710-5, 1990.

21- SCHWABL P., BUCSICS T., SOUCEK K., et al.: Risk factors for development of spontaneous bacterial peritonitis and subsequent mortality in cirrhotic patients with ascites. Liver International, 35 (9): p. 2121-8, 2015.

22- BAR-MEIR S., LERNER E. and CONN H.O.: Analysis of ascitic fluid in cirrhosis. Digestive Diseases and Sciences, 24 (2): p. 136-44, 1979.

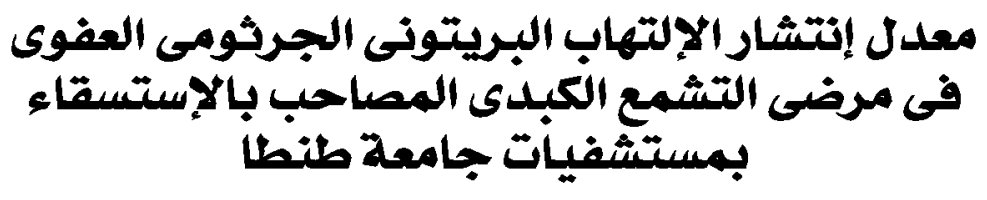

\footnotetext{
تهدف هذه الدراسة إلى معرفة معدل إنتثار الإلتهاب البريتونى الجرثومى العفوى فى مرضى التشمع الكبدى المصاحب بالإستسقاء

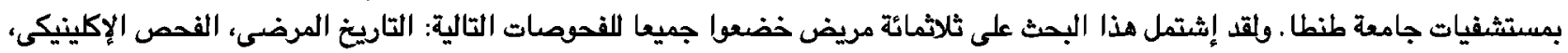

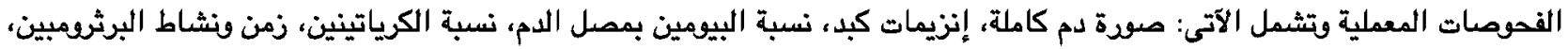

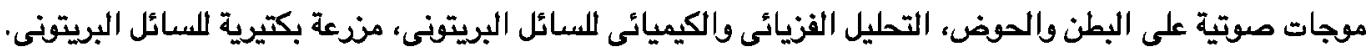
قوثد خلصت الدراسة إلى آن معدل إنتشار الإلتهاب البريتونى الجرثومى العفوى فى مرضى التشمى الكبدى المصاحب بالإستسقاء يمثل

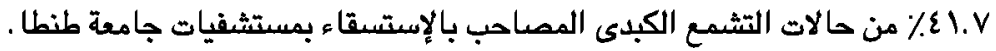

